\title{
DA, Rat Strain
}

National Cancer Institute

\section{Source}

National Cancer Institute. DA, Rat Strain. NCI Thesaurus. Code C14385.

DA: Urinary bladder tumors $54 \%$ in males and $14 \%$ in females, with a peak incidence at 25-30 months of age (Deerberg et al 1985). High incidence of hormone-dependent endometrial adenocarcinoma. A transplantable cell line (RUCA-I) derived from such a tumor in DA rats can produce these tumors in ectopic sites. The rate of proliferation is reduced by tamoxifen, and this cell line appears to be a suitable model for the study of molecular aspects of estrogen and tamoxifen-dependent gene expression. 